\title{
Examination of postextraction space closure speed using elastic chains and NiTi closed coil springs
}

\author{
Mirjana Umićević Davidović, Marijana Arapović Savić, Adriana Arbutina \\ University of Banja Luka, Faculty of Medicine, Department of Orthodontics, Banja Luka, Republika Srpska, Bosnia and \\ Herzegovina
}

\begin{abstract}
SUMMARY
Introduction In everyday clinical practice, we often encounter a lack of space for placing all the teeth present into dental arch; therefore it is often recommended to extract teeth within orthodontic treatment. In clinical practice, the most commonly used methods of closing space after are elastic chains and NiTi closed spiral springs.

The aim of this paper was to compare postextraction space closure speed using two different sliding mechanisms, $\mathrm{NiTi}$ closed coil springs and elastic chains within treatment with fixed orthodontic appliances.

Material and Method The total sample in this study consisted of 46 postexstraction spaces in 23 patients indicated for the extraction of first premolars using treatment with fixed orthodontic appliances. Two sliding mechanisms, NiTi closed coil spring and elastic chains were applied to postextraction space closure. Postextraction spaces were monitored for 4 months with appointments every 4 weeks. During appointments mechanisms were activated and digital caliper was used to measure the width of the postextraction space.

Results The results showed that NiTi closed coil springs method achieved greater reduction in postexstraction space $(3.94 \mathrm{~mm})$ while with elastic chain method the closure of $3.10 \mathrm{~mm}$ was achieved. The total difference between these two methods in the observed period was $0.84 \mathrm{~mm}$ and no statistically significant difference was found $(p>0.05)$. The lowest value for NiTi closed springs was $2.19 \mathrm{~mm}$, while for the elastic chain it was $1.29 \mathrm{~mm}$. The best postextraction space closure was $5.70 \mathrm{~mm}$ and it was completed using NiTi closed springs while for elastic chain the best value was $4.80 \mathrm{~mm}$. Conclusion: NiTi closed coil springs lead to faster closure of postextraction spaces in relation to elastic chain. Since this difference is minimal, in practice, both methods can be used equally.

Keywords: NiTi closed coil springs; elastic chains; postextraction space closure
\end{abstract}

\section{INTRODUCTION}

In everyday clinical practice, a lack of space for alligning all present teeth in dental arch is common problem. There are various clinical procedures that can create additional space in dental arch like expansion, molar distalization, interproximal reduction, protrusion of teeth [1]. Dental arch expansion can be dentoalveolar and skeletal, but for every $4 \mathrm{~mm}$ expansion, only $1 \mathrm{~mm}$ of space is gained along the arch. Molar distalisation requires an additional intra or extraoral anchorage for their movement. Interproximal reduction or stripping is done by grinding of enamel from the aproximal surfaces of the tooth, which must not be more than half of its total thickness. These clinical procedures are carried out in cases when lack of space is not more than $2.5 \mathrm{~mm}$ on one side of dental arch $[2,3]$. However, in some cases, where there is bigger lack of space, teeth extraction is used $[3,4]$.

The teeth that are most often extracted in clinical procedure are first premolars. Postextraction space closure is done by bringing adjacent teeth to the place of extracted first premolar in one phase (en-masse) or in two phases. En-masse retraction of teeth means simultaneously moving all frontal teeth (4 incisors and 2 canines), while the two-phase closure first moves canine into the postextraction space and then incisors. The method to be applied depends on the type of orthodontic maloclusion and therapist skills $[5,6,7]$.

There are various techniques for carrying out this clinical procedure, and proper selection can affect the outcome of the treatment. Two basic techniques that differ in biomechanics are closing loops and sliding mechanics [8].Closing loops are incorporated into the archwire design and transmit force over it to close the space without any friction [9]. Sanjay et al. stated that the closure of postextraction spaces without friction, while producing continuous forces, was the biggest advantage of a loop [10]. On the other hand, Chaudhari et al. stated that large bendings of wire that require precision and orthodontic skills may cause great loss of time, difficulties in determining the strength of applied force, as well patient discomfort as major weaknesses of closing loops [11]. Unlike the loops, force must be applied to sliding mechanism, which can overcome archwire resistance through the bracket system and move the teeth along the archwire, with friction occurring [12].

In clinical practice, the most commonly used mechanisms are elastic chains and NiTi closed coil springs [13]. Mc Laughlin and Benett give advantage to elastic chains 
because they are not expensive, easy to use and can be applied to different clinical cases. However, they must be changed every 4 to 6 weeks due to plaque retention that affects their mechanical properties and leads to force decrease [14]. NiTi closed coil springs have ability to memorize shape and superelasticitiy and therefore retain constant force through the time, which makes them highly reliable [15]. Although difficult to maintain oral hygiene, Wichelhaus found that the presence of plaque does not diminish their mechanical properties. Their disadvantage is that they are expensive, but they do not need to be changed, just reactivated on the control checkups [16].

The aim of this study was to compare postextraction space closure speed using two different sliding mechanisms, NiTi closed coil springs and elastic chains within treatment using fixed orthodontic appliances.

\section{MATERIAL AND METHODS}

The study was carried out at the Faculty of Medicine study program Dentistry in Banja Luka, with the approval of the Ethic Committee of the Institute of Dentistry. The total sample in this study was 46 postextraction spaces in 23 patients who had first premolar extracted for the purpose of orthodontic treatment. Respondents were required to meet the following inclusion criteria: 12-18 years of age at the beginning of treatment, no contraindications for orthodontic treatment, no other extractions (except premolar) and written consent of the examinee or parent. Exclusion criteria for this study were: one or more teeth missing (apart from the third molars), cleft palate or some of the craniofacial syndromes, poor oral hygiene, teeth development anomalies, patients who do not come for checkups regularly, and patients previously treated with fixed orthodontic appliances.

Methodology by McLaughlin et al. was used in the research [14]. After the first premolar extractions, fixed orthodontic appliance (Dentaurum, Discovery, Roth prescription, slot 0.022 in) was placed, and then initial leveling was performed with NiTi round and rectangular archwires before placing stainless steel rectangular arches. Rectangular stainless steel archwire of $0.019 \times 0.025$ in was in the bracket slots for at least 4 weeks to become passive and then an appropriate sliding mechanisms were applied to close the postextraction space according to methodology of Balhoff et al. [17].

Patients were randomly assigned to the two groups according to the type of mechanism used to close the postextraction space:

Group 1: Elastic Chains (American Orthodontics, USA) - 24 post extraction spaces

Elastic chain was placed from the hook of canine bracket to the first molar hook, stretching it to approximately double the initial length. On each subsequent visit it was replaced by a new one.

Group 2: NiTi closed coil spring (American orthodontics, USA) - 22 post extraction spaces

NiTi closed coil spring was placed from the hook of canine bracket to the first molar hook, with the springs not stretched more than $9 \mathrm{~mm}$. It was activated during each appointment.

\section{Measurements}

Postextraction spaces were monitored for 4 months from the beginning of their closure. Control appointments were performed every 4 weeks and it was verified whether the applied mechanisms have been damaged and their activation was performed. Digital vernier caliper (precision $0.01 \mathrm{~mm}$ ) was used to mesure maximum distance from the distal surface of canine to mesial surface of the second premolar at each appointment:

- $\mathrm{T}_{0}$ - at the beginning of the postextraction space closure

- $\mathrm{T}_{1}$ - after 4 weeks

- $\mathrm{T}_{2}$ - after 8 weeks

- $\mathrm{T}_{3}$ - after 12 weeks

- $\mathrm{T}_{4}$ - after 16 weeks

\section{RESULTS}

Post-extraction areas after four months $\left(\mathrm{T}_{0}-\mathrm{T}_{4}\right)$ in the application of the NiTi closed coil spring were at average $3.94 \mathrm{~mm}$ while this value with the elastic chain method was $3.10 \mathrm{~mm}$. The total difference between these two methods in the observed period was $0.84 \mathrm{~mm}$. The lowest value for NiTi closed springs was $2.19 \mathrm{~mm}$, while it was $1.29 \mathrm{~mm}$ for the elastic chain. The maximum movement of tooth into postextraction space after application $\mathrm{NiTi}$ closed coil spring was $5.70 \mathrm{~mm}$, elastic chain $4.80 \mathrm{~mm}$ (Table 1).

Table 1. Descriptive statistics for total sample after four months $\left(\mathrm{T}_{0}-\mathrm{T}_{3}\right)$

Tabela 1. Pokazatelji deskriptivne statistike na ukupnom uzorku posle četiri meseca $\left(\mathrm{T}_{0}-\mathrm{T}_{3}\right)$

\begin{tabular}{|l|c|c|c|c|c|}
\hline & N & M & SD & Min & Max \\
\hline $\begin{array}{l}\text { NiTi closed coil spring } \\
\text { NiTi zatvorena opruga }\end{array}$ & 22 & 3.94 & 1.06 & 2.19 & 5.70 \\
\hline $\begin{array}{l}\text { Elastic chain } \\
\text { Elastični lanac }\end{array}$ & 24 & 3.10 & 1.00 & 1.29 & 4.80 \\
\hline
\end{tabular}

Table 2. Number of closed postextraction spaces on monthly basis depending on the choice of method

Tabela 2. Broj zatvorenih postekstrakcionih prostora na mesečnom nivou zavisno od izbora metode

\begin{tabular}{|c|c|c|c|c|}
\hline & \multicolumn{2}{|c|}{$\begin{array}{c}\text { NiTi closed coil spring } \\
\text { NiTi zatvorena opruga }\end{array}$} & \multicolumn{2}{c|}{$\begin{array}{c}\text { Elastic chain } \\
\text { Elastični lanac }\end{array}$} \\
\hline & $f$ & $\%$ & $f$ & $\%$ \\
\hline 1. & 0 & 0.00 & 0 & 0.00 \\
\hline 2. & 0 & 0.00 & 1 & 4.17 \\
\hline 3. & 7 & 31.81 & 10 & 41.67 \\
\hline 4. & 13 & 59.09 & 20 & 83.33 \\
\hline
\end{tabular}

In the first three months, there was a difference in the speed of space closure in favor of NiTi closed springs, but no statistically significant differences were found between them ( $p>0.05$ ). In the first month the difference was 0.20 $\mathrm{mm}$, in second $0.10 \mathrm{~mm}$ and in third $0.18 \mathrm{~mm}$. Unlike to 
the first three months, statistically significant differences in mean reduction of the postextraction space $(\mathrm{p}<0.05)$ was found in the fourth month in favor of NiTi closed coil springs, giving a difference of $0.29 \mathrm{~mm}$.

After 4 months, using elastic chains, 20 (83.33\%) postextraction spaces were completely closed, while in the NiTi closed coil springs group only 13 (59.09\%) (Table 2).

\section{DISCUSSION}

Effectiveness of postextraction space closure depends on a number of factors, such as the type of brackets, size of archwire and applied mechanism [18]. Also, an important role is played by individual differences, the different structure of periodontal fibers and bone activity in adult patients and children, as well as the resistance of the alveolar bone to pressure and its elastic capacity. Space closing speed depends on when the force begins to apply, as the regenerative bone tissue fills the tooth socket of the extracted tooth for 3 weeks and becomes resistant and solid in 3 months. As the bone tissue becomes tighter, the rate of tooth movement is reduced [19]. More efficient and faster closing of the postextraction space is also affected by the force of the applied mechanism over time. Only mild continuous forces provide an optimal system for the movement of tooth in a biologically acceptable way without adverse effects. Orthodontic tooth movement requires the application of continuous force over a certain period of time, whereby the efficiency increases if the force is maintained for as long as possible [20,21].

Although there are numerous ways to close post-extraction spaces, many authors recommend sliding mechanisms as very effective method using fixed orthodontic appliances [22]. Minimal bending of the wire, quick and simple reactivation and time saving are the advantages that make the sliding mechanism method of choice for most orthodontists [11]. Monini et al. found that $63.8 \%$ of the orthodontists use sliding mechanism for postextraction space closure due to simple use [13]. In a study conducted by Banks et al. in United Kingdom, they found that loops are almost never used while sliding mechanisms are applied in $98 \%$ of cases. Two most commonly used methods are elastic chains and NiTi closed coil springs, and that is why they were subject of our research [23].

In our study, we used methodology of McLaughlin's et al. who used rectangular stainless steel archwires of 0.019 $\mathrm{x} 0.025$ in diameter in brackets with slots 0.022 in. These archwires have maximum rigidity and at the same time provide sufficient free sliding [14]. At the begining, 50 postextraction spaces were observed in 25 patients, however, 4 spaces closed in the leveling phase of the treatment, so they could not be included in the study and the final number was 46 . Control appointments were performed once a month, or every 4 weeks and applied sliding mechanics were activated. In clinical practice, it is common to do control checkups every 4 to 6 weeks. If the appliance produces mild continuous forces and only leads to frontal resorption, no additional activation is required. Frequent activation does not allow proper reparative process to oc- cur and can lead to teeth damage. This can be prevented or decreased with not so frequent activation [20,21,24].

In the current study, at 24 postexstraction spaces elastic chains were applied according to the method of Balhoff et al., based on comparative study using different techniques of placing elastic chain. They came to conclusion that direct placement from molar hook and hook on canine bracket or front hooks on the wire is the most effective, and that is why this method was applied [17]. The results of our study showed that in the observed period of 4 months using elastic chains postextraction space closure was $3.10 \mathrm{~mm}$. In the first three months, spaces were closing faster, while the fourth month showed reduced speed of closure compared to the previous 3 months. These results can be explained by the fact that control appointments and measurements were performed every month, and in the last month there was great number of postextraction spaces already closed (20), where the time between $\mathrm{T}_{3}$ to $\mathrm{T}_{4}$ measurement was also smaller.

Nightingale and Jones observed closure of 20 postextraction spaces on a weekly basis using elastic chains and came to similar results with value of $0.21 \mathrm{~mm}$ [25]. Bokas and Woods conducted study on 22 postexstraction spaces closure using elastic chains within fixed orthodontic treatment with approximately $200 \mathrm{~g}$ of initial force. Their research suggests faster closure of postextraction spaces when using this method (1.68 $\mathrm{mm}$ per month) [26]. Unlike previous authors, Chaudhari and Tarvade came to results with significantly lower values, on average $0.62 \mathrm{~mm}$ per month [11]. The results of Fang et al. research are in agreement with the previous one, with somewhat smaller value of $0.52 \mathrm{~mm}$ [27]. In these researches, en-masse method of tooth movement was used, where the mechanisms were placed at attached hooks on posted stainless steel archwire and molar hook on tube, that resulted in somewhat slower closure of postextraction spaces.

In the current study, NiTi closed coil springs were applied to 22 post exstraction spaces in the same way as elastic chains, except in cases of larger distances when they were placed indirectly. Nightingale et al. recommend the method of indirect placement through steel ligatures in situations where they cannot be placed directly or due to excessive stretching that would result in mechanism damage and undesired effects of tooth movement [25].

The results of our study showed that in the observed period of 4 months, post-extraction space closure of $3.91 \mathrm{~mm}$ was achieved using NiTi closed coil springs. We found that in the first three months the spaces were closing faster, while in the fourth month there was reduced speed compared to the first 3 months. Studies using similar methodology showed actually different results. Nightingale and Jones established $0.26 \mathrm{~mm}$ closure in 20 post extraction spaces on a weekly basis, and that is consistent with our research [25], while the results of Bokas and Woods reported significantly higher values of 1.85 $\mathrm{mm}$ [26]. In studies of Chaudharia and Tarvade, as well as Fang et al. using the en-masse method, the average measured values were $0.87 \mathrm{~mm}$ and $1.06 \mathrm{~mm}[11,27]$.

Comparing the rate of post-extraction spaces closure in observed period, our study found the value greater 
than $0.84 \mathrm{~mm}$ using NiTi closed coil springs. There are numerous studies that compared these two methods and confirmed these results [22, 28, 29]. In addition to these, Dixon et al. also compared active ligatures ie. sliding mechanism consisting of a steel ligature and elastic ring. In their research, NiTi closed coil springs proved to be the fastest mechanism $(0.81 \mathrm{~mm}$ per month), then elastic chains $(0.58 \mathrm{~mm}$ per month) and the slowest active ligature $(0.35 \mathrm{~mm}$ per month). The authors also showed the number of post extraction space closure that was completed in 4 months, which was significantly different from the results obtained in the current study. The highest number of space closures were found in the application of active ligatures (38\%), followed by NiTi closed coil springs (32\%), and at least elastic chains (30\%), while in our study, after 4 months the method of elastic chains and NiTi closed coil springs closed 33\% and 59.09\% of post extraction spaces, respectively. Considering that in both studies most spaces were closed slowly, the conclusion would be that these methods were applied to those spaces that had lower values after the leveling stage of orthodontic treatment [30].

One of the most important factors that affects the speed of tooth movement is the strength and type of applied force. The force produced by elastic chains decreases rapidly in the first 24 hours and then continues to decline until the next control appointment, therefore it can be called intermittent rather than continuous [31]. Nickel titanium alloys have the properties of superelasticity and shape memory, that makes NiTi closed coil springs produce mild continuous forces over a longer period of time. In several in vivo studies, NiTi springs have been shown to provide faster and more reliable space closure, and that is consistent with our research. It is believed that retaining a constant force over a certain period of time contributes most to their efficiency $[16,32]$.

\section{CONCLUSION}

NiTi closed coil springs lead to faster post extraction spaces closure compared to elastic chain. Considering that the difference was minimal with no great clinical significance, in practice, both methods can be used equally to clinician choice.

\section{REFERENCES}

1. Ribeiro GL, Jacob HB. Understanding the basis of space closure in orthodontics for a more efficient orthodontic treatment. Dent Press J Orthod. 2016; 21(2):115-25.

[DOI: 10.1590/2177-6709.21.2.115-125.sar] [PMID: 27275623]

2. Demirović D. Osnove fiksne tehnike u ortodonciji. Stomatološki fakultet Sarajevo; 2005.

3. Ruellas ACO, Ruellas RMO, Romano FL, Pithon MM, Santos RL. Tooth extraction in orthodontics: an evaluation of diagnostic elements. Dental Press J Orthod. 2010; 15(3):134-57. [DOI: 10.1590/S2176-94512010000300017]

4. Travess H, Roberts-Harry D, Sandy J. Orthodontics. Part 8: Extractions in orthodontics. Br Dent J. 2004; 196(4):195-203. [DOI: 10.1038/sj.bdj.4810979] [PMID: 15039723]
5. Felemban NH, Al-Sulaimani FF, Murshid ZA, Hassan AH. En masse retraction versus two-step retraction of anterior teeth in extraction treatment of bimaxillary protrusion. J Orthod Sci. 2013; 2(1):28-37. [DOI: 10.4103/2278-0203.110330] [PMID: 24987640]

6. Heo W, Nahm DS, Baek SH. En Masse Retraction and Two-Step Retraction of Maxillary Anterior Teeth in Adult Class I Women. Angle Orthod. 2007; 77(6):973-8. [DOI: 10.2319/111706-464.1] [PMID: 18004930]

7. Rizk MZ, Mohammed H, Ismael O, Bearn DR. Effectiveness of en masse versus two-step retraction: a systematic review and metaanalysis. Prog Orthod. 2018; 18(1):41.

[DOl: 10.1186/s40510-017-0196-7] [PMID: 29302879]

8. Barlow M, Kula K. Factors influencing efficiency of sliding mechanics to close extraction space: a systematic review. Orthod Craniofac Res. 2008; 11(2):65-73. [DOI: 10.1111/j.1601-6343.2008.00421.x] [PMID: 18416747]

9. Thiesen G, Shimizu RH, Valle CVM, Valle-Corotti KM, Pereira JR, Conti PCR. Determination of the force systems produced by different configurations of tear drop orthodontic loops. Dental Press J Orthod. 2013; 18(2):19.e1-18.

[DOl: 10.1590/S2176-94512013000200007] [PMID: 23916447]

10. Sanjay N, Rajesh RN, Scindia R, Ajith SD. Space closure with loop mechanics for treatment of bimaxillary protrusion: a case report. J Int Oral Health. 2015; 7(5):65-7. [PMID: 26028908]

11. Chaudhari CV, Tarvade SM. Comparison of rate of retraction and anchorage loss using nickel titanium closed coil springs and elastomeric chain during the en-masse retraction: A clinical study. J Orthod Res. 2015; 3:129-33. [DOI: 10.4103/2321-3825.150582]

12. Kojima Y, Fukui $\mathrm{H}$. Numerical simulation of canine retraction by sliding mechanics. Am J Orthod Dentofacial Orthop. 2005; 127(5):542-51. [DOI: 10.1016/j.ajodo.2004.12.007] [PMID: 15877034]

13. Monini AC, Gandini LG, Jr, Santos-Pinto A, Maia LG, Rodrigues WC. Procedures adopted by orthodontists for space closure and Anchorage control. Dental Press J Orthod. 2013; 18(6):86-92. [DOl: 10.1590/S2176-94512013000600013]

14. Mc Laughlin RP, Benett JC, Trevisi H. Systemized Orthodontic Treatment Mechanics. Mosby Elsevier. 2001; 249-77.

15. Maganzini AL, Wong AM, Ahmed MK. Forces of various nickel titanium closed coil springs. Angle Orthod. 2010; 80(1):182-7. [DOl: 10.2319/011509-592.1] [PMID: 19852659]

16. Wichelhaus A. Mechanical behavior and clinical application of nickel-titanium closed-coil springs under different stress levels and mechanical loading cycles. Am J Orthod Dentofacial Orthop. 2010; 137(5):671-8. [DOI: 10.1016/j.ajodo.2008.06.029] [PMID: 20451787]

17. Balhoff DA, Shuldberg M, Hagan JL, Ballard RW, Armbruster PC. Force decay of elastomeric chains-a mechanical design and product comparison study. J Orthod. 2011; 38(1):40-7. [DOI: 10.1179/14653121141227] [PMID: 21367827]

18. Kanuru RK, Azaneen M, Narayana V, Kolasani B, Indukuri RR, Babu PF. Comparison of canine retraction by in vivo method using four brands of elastomeric power chain. Int Soc Prev Community Dent. 2014; 4(1):32-7. [DOI: 10.4103/2231-0762.144586] [PMID: 25452925]

19. Tominaga JY, Ozaki H, Chiang PC, Sumi M, Tanaka M, Koga Y, et al. Effect of bracket slot and archwire dimensions on anterior tooth movement during space closure in sliding mechanics: a 3-dimensional finite element study. Am J Orthod Dentofacial Orthop. 2014; 146(2):166-74. [DOI: 10.1016/j.ajodo.2014.04.016] [PMID: 25085299]

20. Krishnan V, Davidovitch Z. Cellular, molecular, and tissue-level reactions to orthodontic force. Am J Orthod Dentofacial Orthop. 2006; 129:469e.1-469e.32. [DOI: 10.1016/j.ajodo.2005.10.007] [PMID: 16627171]

21. Iwasaki LR, Haack JE, Nickel JC, Morton J. Human tooth movement in response to continuous stress of low magnitude. Am J Orthod Dentofacial Orthop. 2000; 117(2):175-83. [PMID: 10672218]

22. Kulshrestha RS, Tandon R, Chandra P. Canine retraction: A systematic review of different methods used. Orthod Sci. 2015; 4(1):1-8. [DOI: 10.4103/2278-0203.149608] [PMID: 25657985] 
23. Banks P, Elton $\mathrm{V}$, Jones $\mathrm{Y}$, Rice P, Derwent S, Odondi L. The use of fixed appliances in the UK: a survey of specialist orthodontists. J Orthod. 2010; 37(1):43-55. [DOI: 10.1179/14653121042867] [PMID: 20439926]

24. Jerrold L, Naghavi N. Evidence-based considerations for determining appointment intervals. J Clin Orthod 2011; 45(7):379-83. [PMID: 21965318]

25. Nightingale C, Jones SP. A clinical investigation of force delivery systems for orthodontic space closure. J Orthod. 2003; 30(3):229-36. [DOI: 10.1093/ortho/30.3.229] [PMID: 14530421]

26. Bokas J, Woods M. A clinical comparison between nickel titanium springs and elastomeric chains. Aust Orthod J. 2006; 22(1):39-46. [PMID: 16792244]

27. Fang S, Zhong Y, Li M, Luo J, Khadka N, Jiang C, Wang J, Du X. Comparing two methods of orthodontics space closure: a randomized clinical trial. Int J Clin Exp Med. 2017; 10(10):14667-72.

28. Samuels RH, Rudge SJ, Mair LH. A comparison of the rate of space closure using a nickel-titanium spring and an elastic module: a clinical study. Am J Orthod Dentofacial Orthop. 1993; 103(5):464-7. [DOI: 10.1016/S0889-5406(05)81798-6] [PMID: 8480716]
29. Samuels RH, Rudge S), Mair LH. A clinical study of space closure with nickel-titanium closed coil springs and an elastic module. Am J Orthod Dentofacial Orthop. 1998; 114(1):73-9.

[DOI: 10.1016/S0889-5406(98)70241-0] [PMID: 9674684]

30. Dixon V, Read MJ, O'Brien KD, Worthington HV, Mandall NA. A randomized clinical trial to compare three methods of orthodontic space closure. J Orthod. 2002; 29(1):31-6. [DOl: 10.1093/ortho/29.1.31] [PMID: 11907307]

31. Santos AC, Tortamano A, Naccarato SR, Dominguez-Rodriguez GC, Vigorito JW. An in vitro comparison of the force decay generated by different commercially available elastomeric chains and NiTi closed coil springs. Braz Oral Res. 2007; 21(1):51-7. [DOI: 10.1590/S1806-83242007000100009] [PMID: 17384855]

32. Mohammed H, Rizk MZ, Wafaie K, Almuzian M. Effectiveness of nickel-titanium springs vs elastomeric chains in orthodontic space closure: A systematic review and meta-analysis. Orthod Craniofac Res. 2018; 21(1):12-9. [DOI: 10.1111/ocr.12210] [PMID: 29265578]

Received: 14.08.2018 • Accepted: 30.10.2018 


\title{
Ispitivanje brzine zatvaranja postekstrakcionog prostora elastičnim lancem i NiTi zatvorenim spiralnim oprugama
}

\author{
Mirjana Umićević Davidović, Marijana Arapović Savić, Adriana Arbutina \\ Univerzitet u Banjoj Luci, Medicinski fakultet, Katedra za ortopediju vilica, Banja Luka, Republika Srpska, Bosna i Hercegovina
}

\begin{abstract}
KRATAK SADRŽAJ
Uvod U svakodnevnoj kliničkoj praksi se često susrećemo sa nedostatkom prostora za postavljanje svih prisutnih zuba u zubni niz, pa se zato u okviru ortodontske terapije veoma često preporučuje ekstrakcija zuba. U kliničkoj praksi među najčešće korišćenim metodama su elastični lanci i NiTi zatvorene spiralne opruge.

Cilj ovog rada je bio da se uporedi brzina zatvaranja postekstrakcionog prostora primenom dva različita klizna mehanizma, NiTi zatvorenim spiralnim oprugama i elastičnim lancima u okviru terapije fiksnim ortodontskim aparatima.

Materijal i metode rada Ukupan uzorak u istraživanju činilo je 46 postekstrakcionih prostora kod 23 pacijenta kojima je indikovana ekstrakcija prvih premolara i primena fiksnog ortodontskog aparata u cilju sprovođenja terapije. Za zatvaranje postekstrakcionih prostora primenjena su dva klizna mehanizma - NiTi zatvorene spiralne opruge i elastični lanci. Postektrakcioni prostori su praćeni tokom četiri meseca sa kontrolnim pregledima svake četiri sedmice. Na kontrolnim pregledima su aktivirani mehanizmi, a digitalnim nonijusom merene širine postektrakcionih prostora.

Rezultati Rezultati istraživanja pokazuju da posle četiri meseca kod primene NiTi zatvorene opruge dolazi do nešto većeg smanjenja postekstrakcionog prostora, pri čemu je prosečna vrednost kod ove metode iznosila $3,94 \mathrm{~mm}$, u odnosu vrednosti metode elastičnog lanca od 3,10 $\mathrm{mm}$. Ukupna razlika između ove dve metode u posmatranom periodu je bila $0,84 \mathrm{~mm}$ i nije utvrđena statistički značajna razlika $(p>0,05)$. Najmanja vrednost za NiTi zatvorene opruge je iznosila $2,19 \mathrm{~mm}$, dok je za elastični lanac iznosila 1,29 mm. Najveće pomeranje zuba u postekstrakcioni prostor posle primene NiTi zatvorene opruge je iznosilo 5,70 mm, a kod elastičnog lanca $4,80 \mathrm{~mm}$.

Zaključak NiTi zatvorene spiralne opruge dovode do bržeg zatvaranja postekstrakcionih prostora u odnosu na elastični lanac. S obzirom na to da je ova razlika minimalna, u praksi se mogu ravnopravno koristiti obe metode.

Ključne reči: NiTi zatvorene spiralne opruge; elastični lanac; postekstrakcioni prostor
\end{abstract}

\section{UVOD}

U svakodnevnoj kliničkoj praksi kod pacijenata se susrećemo sa nedostatkom prostora za postavljanje svih prisutnih zuba u zubni niz. Postoje razne kliničke procedure kojima se može stvoriti dodatni prostor u zubnom luku koji bi omogućio uslove za postizanje pravilne okluzije. Dodatni prostor u zubnim lukovima se može dobiti njihovim širenjem, distalizacijom molara, interproksimalnom redukcijom, protruzijom zuba [1]. Šrenje ili ekspanzija zubnih lukova može biti dentoalveolarna i skeletna, ali na svaka $4 \mathrm{~mm}$ ekspanzije oslobađa se samo 1 mm prostora duž luka. Distalizacija molara zahteva dodatno intraoralno ili ekstraoralno uporište za njihovo pomeranje. Interproksimalnom redukcijom ili stripovanjem se vrši brušenje gleđi sa aproksimalnih površina zuba koje ne sme da iznosi više od polovine njene ukupne debljine. Ove kliničke procedure se sprovode u slučajevima gde postoji manji nedostatak prostora, odnosno gde nam je potrebno najviše $2,5 \mathrm{~mm}$ prostora sa jedne strane zubnog niza [2,3]. Međutim, u nekim slučajevima gde je veći nedostatak prostora primenjuje se ekstrakcija zuba, odnosno smanjenje broja zuba u zubnom nizu $[3,4]$.

Ortodontska terapija kod koje se primenjuje ekstrakcija zuba ima za cilj postizanje pravilne okluzije, sklada u izgledu lica i stabilnih rezultata lečenja $[3,4]$. U kliničkoj proceduri, u svrhu ortodontske terapije, zubi koji se najčešće ekstrahuju su prvi premolari. Zatvaranje postekstrakcionog prostora se vrši dovođenjem susednih zuba na mesto ekstrahovanog prvog premolara u jednoj fazi (en-masse) ili u dve faze. Pomeranje ili retrakcija zuba en-masse podrazumeva istovremeno pomeranje svih frontanih zuba (četiri sekutića i dva očnjaka), dok se dvofaznim zatvaranjem prvo pomera očnjak u postekstrakcioni prostor, a zatim sekutići. Koja će se metoda primeniti zavisi od vrste ortodontske nepravilnosti i veštine i umeća terapeuta $[5,6,7]$.
Postoje različite tehnike za sprovođenje ove kliničke procedure, a pravilan izbor odgovarajuće može da utiče na ishod terapije. Dve osnovne tehnike koje se razlikuju po biomehanici su mehanizam omči za zatvaranje prostora i klizni mehanizam [8]. Omče su inkorporirane u dizajn žičanog luka i imaju ulogu da preko njega prenesu silu koja dovodi do zatvaranja prostora bez pojave trenja [9]. Sanjay i saradnici navode da zatvaranje postekstrakcionih prostora bez pojave trenja, pri čemu se proizvode kontinuirane sile, predstavlja najveću prednost omči [10]. $S$ druge strane, Chaudhari i saradanci kao glavne nedostatke omči navode velika savijanja žice koja zahtevaju preciznost i veštinu ortodonta, što uzrokuje veliki gubitak vremena, zatim poteškoće u određivanju jačine primenjene sile, kao i nelagodnost koju izazivaju kod pacijenta [11]. Za razliku od omči, kod kliznog mehanizma se mora primeniti sila koja može savladati otpor klizanja žičanog luka kroz sistem bravica i pomeriti zube duž žičanog luka, pri čemu se javlja trenje [12].

U kliničkoj praksi među najčešće korišćenim mehanizmima su elastični lanci i NiTi zatvorene spiralne opruge [13]. Mc Laughlin i Benett daju prednost elastičnim lanacima zato su što nisu skupi, lako se koriste i mogu se primeniti na različite kliničke slučajeve. Međutim, moraju se menjati svakih četiri do šest sedmica zbog zadržavanja plaka, koji utiče na njihova mehanička svojstva i dovodi do očekivanog opadanja sile [14]. NiTi zatvorene spiralne opruge imaju sposobnost memorisanja oblika i superelastičnosti, zbog čega zadržavaju konstantnu silu kroz vreme i zbog čega ih Mangazini i saradnici smatraju veoma pouzdanim [15]. Iako otežavaju održavanje oralne higijene, Wichelhaus je utvrdio da prisustvo plaka ne umanjuje njihove mehaničke osobine. Nedostatak je što su skupi, ali se na kontrolnim pregledima ne moraju menjati, već ponovo aktivirati [16].

Cilj ovog rada je bio da se uporedi brzina zatvaranja postekstrakcionog prostora sa dva različita klizna mehanizma, 
elastičnim lancima i NiTi zatvorenim spiralnim oprugama u okviru terapije fiksnim ortodontskim aparatima.

\section{MATERIJAL I METODE}

Istraživanje je sprovedeno na Medicinskom fakultetu na studijskom programu stomatologija u Banjaluci, uz saglasnost Etičkog komiteta Zavoda za stomatologiju. Ukupan uzorak u istraživanju činilo je 46 postekstrakcionih prostora kod 23 pacijenta kojima je indikovana ekstrakcija prvih premolara u cilju sprovođenja ortodontske terapije. Ispitanici su morali ispunjavati sledeće inkluzione kriterijume: uzrast od 12 do 18 godina na početku terapije, da nema kontraindikacija za ortodontsku terapiju, da nema drugih ekstrakcija (osim premolara) i pismeni pristanak ispitanika ili roditelja. Ekskluzioni kriterijumi za ovu studiju su bili: nedostatak jednog ili više zuba (osim trećih molara), rascep nepca ili neki od kraniofacijalnih sindroma, loša oralna higijena, razvojne anomalije zuba, pacijenti koji neredovno dolaze na kontrole i pacijenti koji su prethodno bili u terapiji fiksnim ortodontskim aparatima.

U istraživanju je korišćena metodologija koju su ustanovili McLaughlin i saradnici [14]. Posle ekastrakcije prvih premolara ispitanicima je postavljen fiksni ortodontski aparat (Dentaurum, Discovery, Roth preskripcija, slot 0,022 in), nakon čega je izvršena početna nivelacija sa NiTi lukovima okruglog i četvrtastog preseka, pre postavljanja čeličnih četvrtastih lukova. Četvrtasti čelični luk preseka $0,019 \times 0,025$ in je stajao u slotovima bravica najmanje četiri sedmice, da bi postao pasivan, posle čega su aplicirani odgovarajući klizni mehanizmi za zatvaranje postekstrakcionih prostora prema metodologiji Balhoffa i saradnika [17].

Ispitanici su metodom slučajnog izbora raspoređeni u dve grupe prema vrsti mehanizma koji se primenjivao za zatvaranje postekstrakcionog prostora:

Grupa 1: Elastični lanci (American Orthodontics, USA) - 24 postekstrakciona prostora

Elastični lanac je postavljan tako da povezuje kukicu na tubi prvog molara i kukicu bravice na očnjaku, pri čemu je rastegnut na približno dvostruku početnu dužinu. Na svakoj narednoj kontroli je bio zamenjen novim.

Grupa 2: NiTi zatvorena spiralna opruga (American orthodontics USA) - 22 postekstrakciona prostora

NiTi zatvorena spiralna opruga je postavljana od kukice na tubi prvog molara do kukice bravice na očnjaku, pri čemu opruge nisu bile istegnute više od $9 \mathrm{~mm}$. Za vreme terapije opruga je aktivirana na kontrolnim pregledima.

\section{Merenja}

Postekstrakcioni prostori su praćeni četiri meseca od početka njihovog zatvaranja. Kontrolni pregledi su obavljani svake četiri sedmice i na njima je proveravano da li je došlo do oštećenja apliciranih mehanizama i izvršena njihova aktivacija. Digitalnim nonijusom (preciznosti $0,01 \mathrm{~mm}$ ) na kontrolnim pregledima $\left(\mathrm{T}_{0}-\mathrm{T}_{4}\right)$ mereno je maksimalno rastojanje od distalne površine očnjaka do mezijalne površine drugog premolara:

- $\mathrm{T}_{0}$ - na početku zatvaranja postekstrakcionog prostora

- $\mathrm{T}_{1}$ - posle četiri sedmice

- $\mathrm{T}_{2}$ - posle osam sedmica

- $\mathrm{T}_{3}$ - posle 12 sedmica

- $\mathrm{T}_{4}$ - posle 16 sedmica

\section{REZULTATI}

Rezultati istraživanja pokazuju da na ukupnom uzorku od 46 postekstrakcionih prostora posle četiri meseca $\left(\mathrm{T}_{0}-\mathrm{T}_{4}\right)$ kod primene NiTi zatvorene opruge dolazi do nešto većeg smanjenja postekstrakcionog prostora, pri čemu je prosečna vrednost kod ove metode iznosila $3,94 \mathrm{~mm}$, u odnosu na vrednost metode elastičnog lanca - 3,10 mm. Ukupna razlika između ove dve metode u posmatranom periodu je bila $0,84 \mathrm{~mm}$. Najmanja vrednost za NiTi zatvorene opruge je iznosila 2,19 mm, dok je za elastični lanac iznosila $1,29 \mathrm{~mm}$. Najveće pomeranje zuba u postekstrakcioni prostor posle primene NiTi zatvorene opruge je iznosilo 5,70 mm, a kod elastičnog lanca 4,80 mm (Tabela 1).

$\mathrm{U}$ prva tri meseca postoji razlika u brzini zatvaranja prostora u korist NiTi zatvorenih opruga, ali nisu utvrđene statistički značajne razlike zavisno od izbora metode $(\mathrm{p}>0,05)$. U prvom mesecu je razlika iznosila $0,20 \mathrm{~mm}$, u drugom $0,10 \mathrm{~mm}$ i u trećem $0,18 \mathrm{~mm}$. Za razliku od prva tri meseca, u četvrtom mesecu su utvrđene statistički značajne razlike u prosečnom smanjenju postekstrakcionog prostora $(\mathrm{p}<0,05)$ u prilog NiTi zatvorenih opruga, pri čemu je dobijena razlika iznosila $0,29 \mathrm{~mm}$.

Posmatrajući promene na mesečnom nivou, utvrđen je veći broj slučajeva zatvaranja postekstrakcionog prostora posle primene elastičnih lanaca u odnosu na NiTi zatvorene opruge. Četiri meseca posle primene elastičnih lanaca došlo je do zatvaranja $20(83,33 \%)$ postekstrakcionih prostora, dok je pomoću NiTi zatvorenih opruga zatvoreno 13 postekstrakcionih prostora $(59,09 \%)$ (Tabela 2$)$.

\section{DISKUSIJA}

Efikasnost zatvaranja postekstrakcionih prostora zavisi od brojnih faktora, kao što su vrsta bravica, veličina žice i primenjenog mehanizma [18]. Takođe, važnu ulogu imaju individualne razlike, različita struktura periodontalnih vlakana i koštane aktivnosti kod odraslih pacijenata i dece, kao i otpornost alveolarne kosti na pritisak i njen elastični kapacitet. Brzina zatvaranja prostora zavisi i od toga kada se počinje sa primenom sile, pošto regenerativno koštano tkivo popunjava alveolarnu čašicu ekstrahovanog zuba za tri sedmice i postaje otporno i čvrsto za tri meseca. Kako koštano tkivo postaje čvršće, smanjuje se brzina pomeranja zuba [19]. Na efikasnije i brže zatvaranje postekstrakcionog prostora utiče i opadanje sile primenjenog mehanizma kroz vreme. Samo blage kontinuirane sile obezbeđuju optimalan sistem sila za pomeranje zuba na biološki prihvatljiv način bez neželjenih efekata. Ortodontsko pomeranje zuba zahteva primenu kontinuirane sile kroz određeni period, pri čemu se efikasnost povećava ukoliko se jačina sile održi što duže $[20,21]$.

Iako postoje brojni načini za zatvaranje postekstrakcionih prostora, mnogi autori preporučuju klizne mehanizme kao veoma efikasnu metodu u okviru terapije fiksnim ortodontskim aparatima [22]. Minimalno savijanje žice, brza i jednostavna reaktivacija i ušteda vremena su prednosti zbog kojih klizni mehanizam predstavljaju metodu izbora kod većine ortodonata [11]. Monini i saradnici su ustanovili da 63,8\% ortodonata koristi klizni mehanizam prilikom zatvaranja postekstrakcionog prostora u okviru terapije fiksnim ortodontskim aparatima zbog jednostavnosti i lakoće primene [13]. U studiji koju su sproveli Banks i saradnici u Velikoj Britaniji ustanovljeno je da se opruge 
gotovo i ne koriste, dok se klizni mehanizmi primenjuju u $98 \%$ slučajeva. Kao dve najčešće korišćene metode navode se elastični lanci i NiTi zatvorene spiralne opruge, zbog čega su one predmet ovog istraživanja [23].

U ovom istraživanju je primenjena metodologija McLaughlina i saradnika, koji su utvrdili da su četvrtasti čelični lukovi promera $0,019 \times 0,025$ in u bravicama slota 0,022 in najefikasniji za primenu kliznih mehanizama zato što imaju maksimalnu rigidnost, a istovremeno obezbeđuju dovoljno slobode za klizanje [14]. Na početku je posmatrano 50 postekstrakcionih prostora kod 25 pacijenata, međutim četiri prostora su se zatvorila u nivelacionoj fazi terapije, zbog čega nisu mogla biti uključena u istraživanje, tako da je konačan broj iznosio 46. Kontrolni pregledi, na kojima su se primenjeni klizni mehanizmi aktivirali, obavljani su jednom mesečno, odnosno svake četiri sedmice. U kliničkoj praksi je uobičajeno da se kontrolni pregledi zakazuju na četiri do šest sedmica. Ukoliko aparat proizvodi blage kontinuirane sile i dovodi samo do frontalne resorpcije, nije potrebna dodatna aktivacija. Učestale aktivacije aparata ne dozvoljavaju da se desi odgovarajući reparativni proces, što može dovesti do oštećenja zuba. Ovo se može sprečiti ili umanjiti sa ne tako čestim aktiviranjem [20,21,24].

U ovom istraživanju su posmatrana 24 postekstrakciona prostora kod kojih su primenjeni elastični lanci po metodologiji Balhoffa i saradnika. Na osnovu studije u kojoj su poredili različite tehnike postavljanja elastičnih lanaca došli su do zaključka da je direktno povezivanje kukice na molaru i bravice na očnjaku ili prednje kukice na žici najefikasnije, zbog čega je ovaj metod primenjen i u ovom istraživanju [17]. Rezultati ovog istraživanja pokazuju da su se u posmatranom periodu od četiri meseca elastičnim lancima postekstrakcioni prostori zatvorili za 3,10 mm. U prva tri meseca prostori se više zatvaraju, dok četvrti mesec pokazuje smanjenu brzinu zatvaranja postektrakcionog prostora u odnosu na prethodna tri meseca. Ovi rezultati se mogu objasniti činjenicom da su kontrole i merenja obavljani svakih mesec dana, a da je u poslednjem mesecu došlo do najvećeg broja zatvaranja postekstrakcionih prostora (20), gde su i rastojanja pri merenju od $\mathrm{T}_{3}-\mathrm{T}_{4}$ bila manja.

Do sličnih rezultata su došli i Nightingale i Jones, koji su posmatrali zatvaranje 20 postekstrakcionih prostora primenom elastičnih lanaca na sedmičnom nivou, koje je iznosilo $0,21 \mathrm{~mm}$ [25]. Bokas i Woods su sproveli istraživanje u kojem su isitivali zatvaranje 22 postekstrakciona prostora pomoću elastičnih lanaca u okviru terapije fiksnim ortodontskim aparatom sa inicijalnom silom približno 200 g. Njihovo istraživanje govori u prilog bržeg zatvaranja postekstrakcionih prostora prilikom korišćenja ove metode (1,68 mm mesečno) [26]. Za razliku od prethodnih autora, Chaudhari i Tarvade su došli do rezultata sa značajno manjim vrednostima, koja u proseku iznose $0,62 \mathrm{~mm}$ mesečno [11]. Rezultati istraživanja Fanga i saradnika su u saglasnosti sa prethodnim, pri čemu je ta vrednost nešto manja i iznosila je 0,52 mm [27]. U ovim istraživanjima korišćena je metoda en-masse pomeranja zuba, gde su se mehanizmi postavljali na kukice koje su lotovane na čeličnu žicu i za kukicu na tubi, što je rezultiralo nešto sporijim zatvaranjem postekstrakcionih prostora.

NiTi zatvorene opruge su u ovom istraživanju primenjene na 22 postekstrakciona prostora na isti način kao i elastični lanci, osim u slučajevima gde su veća rastojanja, zbog čega su postavljani indirektno. Nightingale i saradnici preporučuju metodu indirektnog povezivanja preko čeličnih ligatura u situacijama gde ih nije moguće postaviti direktno ili zbog prevelikog isteza- nja, što bi za posledicu imalo oštećenje mehanizma i neželjene efekte na pomeranje zuba [25].

Rezultati ovog istraživanja pokazuju da su se u posmatranom periodu od četiri meseca postekstrakcioni prostori pomoću $\mathrm{NiTi}$ zatvorenih opruga zatvorili za 3,94 mm. Utvrđeno je da se u prva tri meseca prostori više zatvaraju, dok četvrti mesec pokazuje smanjenu brzinu u odnosu na prethodna tri meseca. Istraživanja u kojima je korišćena slična metodologija pokazuju različite rezultate. Nightingale i Jones su na sedmičnom nivou ustanovili zatvaranje za $0,26 \mathrm{~mm}$ kod 20 postekstrakcionih prostora, što je u skladu sa rezultatima ovog istraživanja [25], dok rezultati Bokasa i Woodsa pokazuju značajno veće vrednosti, koje iznose $1,85 \mathrm{~mm}$ [26]. U istraživanjima Chaudharia i Tarvade, kao i Fanga i saradnika u kojima je korišćena en-masse metoda, prosečne izmerene vrednosti su iznosile $0,87 \mathrm{~mm}$ i 1,06 mm [11,27].

Prilikom poređenja brzine zatvaranja postekstrakcionih prostora u posmatranom periodu, ovim istraživanjem je ustanovljeno da je primenom NiTi zatvorenih spiralnih opruga vrednost veća za $0,84 \mathrm{~mm}$ u odnosu na elastične lance. Postoji veliki broj istraživanja u kojima su se poredile ove dve metode i koja potvrđuju ove rezultate $[22,28,29]$. Dixon i saradnici, pored navedenih, poredili su i aktivne ligature, odnosno klizni mehanizam koji se sastoji od čelične ligature i elastičnog prstena. I u njihovom istraživanju su se NiTi zatvorene spiralne opruge pokazale kao najbrži mehanizam ( $0,81 \mathrm{~mm}$ mesečno), zatim elastični lanci $(0,58 \mathrm{~mm}$ mesečno) i najsporije - aktivne ligature ( $0,35 \mathrm{~mm}$ mesečno). Autori su takođe prikazali i broj zatvaranja postekstrakcionih prostora koji su završeni za četiri meseca, što se značajno razlikuje od rezultata dobijenih u ovoj studiji. Najveći broj zatvorenih prostora su ustanovili kod primene aktivnih ligatura (38\%), zatim NiTi zatvorenih spiralnih opruga (32\%), a najmanje kod elastičnih lanaca (30\%), dok se u ovom istraživanju posle četiri meseca kod metode elastičnih lanaca zatvorilo čak 83,33\%, a kod NiTi zatvorenih spiralnih opruga $59,09 \%$ postekstrakcionih prostora. S obzirom na to da su se i u jednom i u drugom istraživanju najviše zatvarali prostori kod primene mehanizama koji su ga najsporije zatvarali, zaključak je da su ove metode primenjene kod onih prostora koji su imali manje vrednosti posle nivelacione faze ortodontske terapije [30].

Jedan od najvažnijih faktora koji utiče na brzinu pomeranja zuba su jačina i vrsta sile koja se primenjuje. Sila koju proizvode elastični lanci opada ubrzano u prva 24 sata i zatim nastavlja da opada i dalje sve do sledećeg kontrolnog pregleda, zbog čega se ova sila pre može nazvati intermitentna nego kontinuirana [31]. Nikl-titanijumske legure imaju osobine superelastičnosti i memorisanja oblika, zbog čega NiTi zatvorene opruge proizvode blage kontinuirane sile kroz duži period. U nekoliko in vivo studija NiTi opruge su pokazale da obezbeđuju brže i pouzdanije zatvaranje prostora, što je u skladu sa ovim istraživanjem. Smatra se da zadržavanje konstantne sile kroz određeni period najviše doprinosi njihovoj efikasnosti $[16,32]$.

\section{ZAKLJUČAK}

NiTi zatvorene spiralne opruge dovode do bržeg zatvaranja postekstrakcionih prostora u odnosu na elastični lanac. S obzirom na to da je ova razlika minimalna i da nema veliki klinički značaj, u praksi se mogu ravnopravno koristiti obe metode prema izboru kliničara. 